\title{
Profil Paparan Asap Rokok Lingkungan pada Pasien Kanker Payudara di Sumatera Barat Tahun 2020
}

\author{
Fathma Mardhotilla ${ }^{1}$, Wirsma Arif Harahap ${ }^{2}$, Yuniar Lestari ${ }^{3}$ \\ ${ }^{1}$ Fakultas Kedokteran Universitas Andalas, Padang \\ ${ }^{2}$ Bagian Bedah Fakultas Kedokteran Universitas Andalas/ RSUP Dr. M. Djamil, Padang \\ ${ }^{3}$ Bagian IImu Kesehatan Masyarakat Fakultas Kedokteran Universitas Andalas, Padang
}

\section{A B S T R A C T}

\begin{abstract}
Latar Belakang. Kanker payudara merupakan keganasan pada perempuan terbanyak kedua di dunia dan merupakan keganasan dengan tingkat kejadian tertinggi kedua di Indonesia. Kanker payudara disebabkan oleh faktor risiko yang dapat dimodifikasi dan tidak dapat dimodifikasi. Salah satu faktor risiko yang dapat dimodifikasi yang dicurigai menyebabkan kanker payudara adalah paparan asap rokok lingkungan, baik paparan asap rokok dari suami, rekan kerja, dan orang tua saat kecil.
\end{abstract}

Objektif. Mengetahui profil paparan asap rokok lingkungan pada pasien kanker payudara di Sumatera Barat tahun 2020.

Metode. Penelitian ini merupakan penelitian deskriptif dengan jumlah sampel sebanyak 107 orang pasien yang sedang rawat jalan atau rawat inap di di Bagian Bedah RSUP Dr. M. Djamil, RS Pendidikan Universitas Andalas, dan RSI Ibnu Sina Padang dari Januari 2020 - Maret 2020.

Hasil. Sebanyak $90(84,1 \%)$ pasien terpapar asap rokok lingkungan.

Simpulan. Pasien yang terpapar asap rokok lingkungan lebih banyak lima kali lipat daripada yang tidak terpapar asap rokok lingkungan.

Kata kunci: kanker payudara, faktor risiko yang dapat dimodifikasi, paparan asap rokok lingkungan, Sumatera Barat

Background. Breast cancer is the second most common malignancy in women in the world and the second highest malignancy incidence rate in Indonesia. Breast cancer is caused by modifiable and non-modifiable risk factors. One of the modifiable risk factors factor suspected of causing breast cancer is exposure to environmental cigarette smoke, such as exposure to cigarette smoke from husband, coworkers, and parents as a child.

Objective. To determine the he profile of environmental cigarette smoke exposure in breast cancer patients in West Sumatra in 2020.

Method. This research is a descriptive study with a sample of 107 patients who are being treated as outpatients or inpatients in the Department of Surgery Dr. M. Djamil, Andalas University Hospital, and Ibnu Sina Padang Hospital from January 2020 March 2020.
Result. 90 (84.1\%) patients were exposed to environmental cigarette smoke

Conclusion. Patients who are exposed to environmental cigarette smoke are lima times more likely than those who are not exposed

Keyword: breast cancer, modifiable risk factor, environmental cigarette smoke, West Sumatra

\section{Apa yang sudah diketahui tentang topik ini?}

Asap rokok merupakan faktor risiko kanker payudara, baik itu perokok aktif maupun perokok pasif.

\section{Apa yang ditambahkan pada studi ini?}

Sebanyak 90 (84,1\%) pasien terpapar asap rokok lingkungan, yaitu lima kali lebih banyak daripada yang tidak terpapar.

\section{CORRESPONDING AUTHOR}

Name: Fathma Mardhotilla

Phone: +6285356029992

E-mail: fathmardhotilla@gmail.com

\section{ARTICLE INFORMATION}

Received: September $23^{\text {rd }}$, 2020

Revised: October $15^{\text {th }}, 2020$

Available online: October $31^{\text {st }}, 2020$ 


\section{Pendahuluan}

Kanker payudara adalah pertumbuhan sel-sel payudara yang tidak terkendali yang dapat menyerang organ di sekitarnya dan dapat bermetastasis ke organ yang jauh.1,2 Kanker payudara merupakan kanker dengan angka kejadian kedua terbanyak di dunia setelah kanker paru dan merupakan kanker yang paling banyak diderita perempuan di antara kanker lainnya. ${ }^{3}$ Angka kejadian kanker payudara mengalami kenaikan. Pada tahun 2008 terdapat 12,7 juta kasus baru baru kanker payudara, 1.7 juta kasus baru pada tahun 2012, dan 2.089 juta kasus baru kanker payudara pada tahun 2018.3,4 Pada tahun 2018, angka kematian akibat kanker payudara berkisar 6,6\% atau sekitar 627.000 kematian di antara semua kematian yang disebabkan oleh kanker. ${ }^{4}$

Angka kejadian kanker payudara pada tahun 2018 di berbagai wilayah berbeda-beda. Insiden tertinggi terjadi di Australia/ New Zeeland dengan angka kejadian 94,2 per 100.000 penduduk, diikuti Eropa Barat dengan angka kejadian 92,6 per 100.000 penduduk, lalu Eropa Timur dengan angka kejadian 90,1 per 100.000 penduduk. Sedangkan Asia Tenggara berada pada urutan ke17 dengan angka kejadian 38,1 per 100.000 penduduk. ${ }^{3}$

Kanker payudara merupakan penyakit kanker dengan prevalensi tertinggi kedua di Indonesia yaitu $0,5 \%$ setelah kanker serviks $(0,8 \%){ }^{6}$ Merujuk data yang dipaparkan Kemenkes per 31 Januari 2019, terdapat 42,1 kejadian kanker payudara per 100.000 penduduk dengan ratarata kematian 17 per 100.000 penduduk. ${ }^{7}$ Tahun 2013, terdapat 61.682 perempuan menderita kanker payudara di Indonesia dengan 2.285 jumlah kasus berada di Sumatera Barat. ${ }^{8}$ Berdasarkan data rekam medis RSUP Dr. M. Djamil, pasien rawat jalan kanker payudara berjumlah 2.082 orang pada tahun 2014, sebanyak 972 orang pada tahun 2015, meningkat menjadi 4.132 orang pada tahun 2016, dan 1.941 orang pada tahun 2017. Sedangkan pasien rawat inap kanker payudara berjumah 241 orang pada tahun 2014, sebanyak 155 orang pada tahun 2015, sebanyak 109 orang pada tahun 2016, dan 165 orang pada tahun $2017 .{ }^{9}$

Faktor penyebab kanker payudara dapat dikelompokkan ke dalam faktor yang dapat dimodifikasi dan faktor yang tidak dapat dimodifikasi.10 Faktor yang dapat dimodifikasi diantaranya ialah riwayat Air Susu Ibu (ASI) Ekslusif, pilihan metode (KB), kebiasaan diet, aktivitas fisik, dan paparan asap rokok, sedangkan faktor yang tidak dapat dimodifikasi diantaranya ialah usia, jenis kelamin, riwayat keluarga, usia menarche, dan riwayat tumor di payudara sebelumnya. ${ }^{10}$

Berbeda dari faktor risiko kanker payudara lain yang dapat dimodifikasi, paparan asap rokok merupakan faktor yang dapat dimodifikasi, tetapi sulit dikontrol karena berhubungan dengan perilaku orang lain. Seseorang yang tidak merokok belum tentu dapat terhindar dari paparan asap rokok, orang tersebut bisa terpapar asap rokok lingkungan dari orang sekitarnya yang disebut sebagai perokok pasif. Paparan asap rokok lingkungan merupakan kombinasi dari dua jenis asap yaitu mainstream smoke dan sidestream smoke. Mainstream smoke atau asap rokok utama adalah asap rokok yang dihirup lalu dikeluarkan oleh perokok dan sidestream smoke atau asap samping adalah asap yang diemisikan dari ujung rokok. Kedua jenis asap ini terdiri dari komponen toksik karsinogenik yang sama, tetapi asap samping lebih terkosentrasi dan mengandung partikel yang lebih kecil daripada asap utama, sehingga membuatnya lebih mudah terhirup. ${ }^{11}$

Komponen kimia utama rokok yang yang dikonversi menjadi asap rokok berjumlah 5300 senyawa, seperti nikotin, N-nitrosamin, hidrokarbon aromatik polisiklik (PAH), amina aromatik, aldehida, dibenzo[a,1]pyrene, dan senyawa organik dan anorganik lainnya. Di antara senyawa-senyawa tersebut terdapat lebih dari 50 zat karsinogenik dan sekitar 20 zat tersebut merupakan karsinogenik kanker payudara. ${ }^{12}$

Jumlah perokok di dunia semakin meningkat dari tahun ke tahun. Menurut data dari WHO, terdapat sekitar 1,1 miliar orang di dunia aktif merokok, jumlah itu merupakan 1/7 dari seluruh populasi manusia di dunia. Indonesia sendiri merupakan negara dengan jumlah perokok terbesar ke-3 di dunia. Laporan Southeast Asia Tobacco Control Alliance (SEATCA) berjudul The Tobacco Control Atlas, Asean Region menunjukkan Indonesia merupakan negara dengan jumlah perokok terbanyak di Asia Tenggara, yakni 65,190 juta orang. Angka tersebut setara 24\% dari total penduduk Indonesia pada 2016.13 Menurut Riskesdas 2018, proporsi perokok di Sumatera 
Barat sendiri adalah 26,9\% yang merupakan urutan ke-7 di antara semua provinsi di Indonesia, sedangkan proporsi frekuensi masyarakat Sumatera Barat berada di dekat orang yang merokok di dalam ruangan tertutup, yaitu rumah, tempat kerja, dan sarana transportasi berada pada posisi pertama di Indonesia. ${ }^{14} \mathrm{Hal}$ ini menyebabkan kemungkinan seseorang untuk terpapar asap rokok lingkungan menjadi sangat tinggi.

Peningkatan jumlah perokok pasif di Indonesia meningkat dari tahun ke tahun. Pada tahun 2007, 91 juta penduduk semua umur terpajan asap rokok di dalam rumah, 92 juta penduduk pada tahun 2010, dan 96 juta jiwa pada tahun 2013.15 Berdasarkan laporan Global Adult Tobacco Survey (GATS) tahun 2011, sebanyak 51,3\% atau sekitar 14,6 juta orang dewasa terpapar asap rokok di tempat kerja, $78,4 \%$ terpapar asap rokok di rumah, 85,4\% terpapar asap rokok di restoran, dan sekitar 70\% terpapar di transportasi publik. ${ }^{16}$

Oleh sebab itu, peneliti tertarik untuk meneliti profil paparan asap rokok lingkungan pada pasien kanker payudara yang bertujuan untuk memberikan data awal dan informasi mengenai faktor risiko lain kanker payudara.

\section{Metode}

Jenis penelitian ini adalah deskriptif retrospektif. Populasi penelitian ini adalah pasien kanker payudara yang datang ke poli dan dirawat inap di Bagian Bedah RSUP Dr. M. Djamil, RS Pendidikan Universitas Andalas, dan RSI Ibnu Sina Padang dari Januari 2020 - Maret 2020. Sampel penelitian ini adalah pasien kanker payudara yang datang ke poli dan dirawat inap di Bagian Bedah RSUP Dr. M. Djamil, RS Pendidikan Universitas Andalas, dan RSI Ibnu Sina Padang dari Januari 2020 - Maret 2020 yang memenuhi kriteria inklusi. Kriteria inklusi: Perempuan, berusia 40 65 tahun, tidak merokok. Kriteria ekslusi: tidak menikah dan tidak memiliki anak. Jumlah sampel yang memenuhi kriteria inklusi yaitu sebanyak 107 orang. Penelitian ini telah lulus kaji etik dengan nomor surat: 66/KEPK/2020.
Hasil

\section{Karakteristik Pasien}

Tabel 1. Distribusi Frekuensi Karakteristik Pasien

\begin{tabular}{|c|c|c|}
\hline Karakteristik & f & $\%$ \\
\hline \multicolumn{3}{|l|}{ Usia } \\
\hline$<50$ tahun & 42 & 39,3 \\
\hline$\geq 50$ tahun & 65 & 60,7 \\
\hline \multicolumn{3}{|l|}{ Tingkat Pendidikan } \\
\hline SD & 14 & 13,1 \\
\hline SMP & 10 & 9,3 \\
\hline SMA & 41 & 38,3 \\
\hline DII/ DIII/ S1/ S2 & 42 & 39,3 \\
\hline \multicolumn{3}{|l|}{ Pekerjaan } \\
\hline Ibu Rumah Tangga & 64 & 59,8 \\
\hline Pedagang, Penjahit, Petani & 3 & 2,8 \\
\hline $\begin{array}{l}\text { Guru, PNS, Polwan, Pegawai Swasta, } \\
\text { Pensiunan }\end{array}$ & 40 & 37,4 \\
\hline \multicolumn{3}{|l|}{ Usia Menarche } \\
\hline$<12$ tahun & 6 & 5,6 \\
\hline$\geq 12$ tahun & 101 & 94,4 \\
\hline \multicolumn{3}{|l|}{ Jumlah Paritas } \\
\hline $1-2$ & 40 & 37,4 \\
\hline $3-4$ & 59 & 55,1 \\
\hline$>4$ & 8 & 7,5 \\
\hline \multicolumn{3}{|l|}{ Lama Laktasi } \\
\hline Tidak pernah & 12 & 11,2 \\
\hline$<12$ bulan & 7 & 6,5 \\
\hline$\geq 12$ bulan & 88 & 82,2 \\
\hline \multirow{2}{*}{\multicolumn{3}{|c|}{ Penggunaan (Keluarga Berencana) KB }} \\
\hline & & \\
\hline Tidak pernah & 38 & 35,5 \\
\hline$<5$ tahun & 52 & 48,6 \\
\hline$\geq 5$ tahun & 17 & 15,9 \\
\hline Jumlah & 107 & 100 \\
\hline
\end{tabular}

Pada penelitian ini, ditemukan bahwa $60,7 \%$ pasien berusia $\geq 50$ tahun. Tingkat pendidikan terbanyak adalah sekolah tinggi sebesar 39,3\%. Sebanyak 59,8\% pasien merupakan ibu rumah tangga. Usia menarche pasien terbanyak adalah $\geq$ 12 tahun sebesar $94,4 \%$. Sebanyak 55,1\% pasien paritas $3-4$ kali. Durasi terbanyak pasien menyusui adalah $\geq 12$ bulan yaitu sebesar $82,2 \%$. Pasien menggunakan KB terbanyak <5tahun sebesar $48,6 \%$.

\section{Paparan Asap Rokok Lingkungan Keseluruhan}

Tabel 2. Distribusi Frekuensi Paparan Asap Rokok Lingkungan Keseluruhan

\begin{tabular}{lccc}
\hline \multicolumn{2}{c}{ Paparan Asap Rokok Lingkungan } & f & \% \\
\hline $\begin{array}{l}\text { Terpapar asap rokok lingkungan } \\
\text { Tidak terpapar asap rokok }\end{array}$ & 90 & 84,1 \\
lingkungan & 17 & 15,9 \\
\hline Total & & 107 & 100 \\
\hline
\end{tabular}

Tabel di atas menunjukkan distribusi frekuensi paparan asap rokok lingkungan pada penderita kanker payudara. Responden yang terpapar asap rokok lingkungan sebanyak $84,1 \%$, 
yaitu lima kali lipat lebih banyak daripada responden yang tidak terpapar asap rokok lingkungan.

\section{Paparan Asap Rokok Lingkungan Berdasarkan Kategori}

Tabel 3. Distribusi Frekuensi Paparan Asap Rokok Lingkungan Berdasarkan Kategori

\begin{tabular}{|c|c|c|}
\hline $\begin{array}{c}\text { Paparan Asap Rokok Lingkungan } \\
\text { Berdasarkan Kategori }\end{array}$ & f & $\%$ \\
\hline \multicolumn{3}{|l|}{$\begin{array}{l}\text { Paparan asap rokok lingkungan } \\
\text { oleh suami }\end{array}$} \\
\hline Terpapar & 57 & 53,3 \\
\hline Tidak terpapar & 50 & 46,7 \\
\hline \multicolumn{3}{|l|}{ Lama paparan dalam sehari } \\
\hline 0 & 50 & 46,7 \\
\hline$<1$ jam & 24 & 22,4 \\
\hline$\geq 1$ jam & 33 & 30,8 \\
\hline \multicolumn{3}{|l|}{ Lama paparan } \\
\hline 0 & 50 & 46,7 \\
\hline $1-10$ tahun & 5 & 4,7 \\
\hline $11-20$ tahun & 16 & 15,0 \\
\hline $21-30$ tahun & 23 & 21,5 \\
\hline$>30$ tahun & 13 & 46,4 \\
\hline \multicolumn{3}{|l|}{$\begin{array}{l}\text { Paparan asap rokok lingkungan } \\
\text { oleh rekan kerja }\end{array}$} \\
\hline Terpapar & 21 & 19.6 \\
\hline Tidak terpapar & 86 & 80,4 \\
\hline \multicolumn{3}{|l|}{ Lama paparan dalam sehari } \\
\hline 0 & 86 & 80,4 \\
\hline$<1$ jam & 5 & 4,7 \\
\hline$\geq 1$ jam & 16 & 15,0 \\
\hline \multicolumn{3}{|l|}{ Lama paparan } \\
\hline 0 & 86 & 80,4 \\
\hline $1-10$ tahun & 5 & 4,7 \\
\hline $11-20$ tahun & 5 & 4,7 \\
\hline $21-30$ tahun & 6 & 5,6 \\
\hline$>30$ tahun & 5 & 83,3 \\
\hline \multicolumn{3}{|l|}{$\begin{array}{l}\text { Paparan asap rokok lingkungan } \\
\text { oleh orang tua }\end{array}$} \\
\hline Terpapar & 59 & 55,1 \\
\hline Tidak terpapar & 48 & 44,9 \\
\hline \multicolumn{3}{|l|}{ Lama paparan dalam sehari } \\
\hline 0 & 48 & 44,9 \\
\hline$<1$ jam & 26 & 24,3 \\
\hline$\geq 1$ jam & 33 & 30,8 \\
\hline \multicolumn{3}{|l|}{ Lama paparan } \\
\hline 0 & 48 & 44,9 \\
\hline $1-10$ tahun & 8 & 7,5 \\
\hline $11-20$ tahun & 29 & 27,1 \\
\hline $21-30$ tahun & 14 & 13,1 \\
\hline$>30$ tahun & 8 & 7,5 \\
\hline Total & 107 & 100 \\
\hline
\end{tabular}

Responden pada penelitian ini lebih banyak terpapar asap rokok lingkungan dari orang tua dibandingkan dari suami. Sebanyak 59 responden $(55,1 \%)$ terpapar asap rokok dari orang tua, sebanyak 57 responden (53,3\%) terpapar asap rokok dari suami, dan sebanyak 21 responden $(19,6 \%)$ kelompok kasus terpapar asap rokok lingkungan dari rekan kerja.
Untuk lama paparan dalam sehari, paparan asap rokok lingkungan dari suami, rekan kerja, dan orang tua selama lebih dari dan sama dengan satu jam dalam sehari lebih banyak daripada yang terpapar kurang dari satu jam dalam sehari yaitu sebanyak 33 responden $(30,8 \%)$ oleh suami dan orang tua, dan sebanyak 16 responden $(15,0 \%)$ dari rekan kerja.

Responden yang terpapar asap rokok lingkungan dari suami dan rekan kerja lebih banyak pada rentang 21 - 30 tahun, yaitu sebanyak 23 responden (21,5\%) oleh suami dan 6 responden $(5,6 \%)$ oleh rekan kerja. Paparan dari orang tua terbanyak berada pada rentang $11-20$ tahun yaitu sebanyak 23 responden $(21,5 \%)$.

\section{Pembahasan}

Perokok aktif maupun orang yang terpapar asap rokok lingkungan berisiko menderita berbagai macam penyakit. Asap rokok menyebabkan 3 juta kematian akibat penyakit kardiovaskuler di dunia setiap harinya. Perempuan yang terpapar asap rokok lingkungan saat hamil meningkatkan risiko keguguran, kematian janin, lahir mati, bayi lahir premature, dan bayi dengan berat badan lahir rendah. ${ }^{17}$ Perempuan yang terpapar asap rokok lingkungan sejak anak-anak berisiko tiga kali terkena kanker paru dibandingan yang tidak terpapar. ${ }^{18}$ Kandungan asap rokok bersifat karsinogenik, sehingga dapat menyebabkan kanker, seperti kanker paru, kanker serviks, dan kanker payudara.

Berdasarkan penelitian yang dilakukan oleh Miftahul Janah dan Santi Martini (2017), diketahui bahwa perempuan usia muda sudah terpapar asap rokok lingkungan selama 5-10 tahun, yang berarti responden sudah terpapar asap rokok lingkungan dimulai sejak mereka masih kecil, terutama apabila responden tinggal serumah dengan orang tua maupun anggota keluarga lain yang memiliki kebiasaan merokok. ${ }^{77}$ Data WHO pada tahun 2014 menunjukkan bahwa terdapat $61,7 \%$ perempuan yang berusia 13 - 15 tahun dari semua remaja terpapar asap rokok di rumah. ${ }^{78}$ Berdasarkan GATS tahun 2011, 75,4\% perempuan terpapar asap rokok di rumah dan 41,8\% perempuan terpapar di tempat kerja. ${ }^{20}$

Responden pada penelitian ini, baik kelompok kasus maupun kelompok kontrol terpapar asap rokok lingkungan paling banyak pada rentang 11 
- 20 tahun. Berbeda dengan penelitian ini, penelitian yang dilakukan oleh Li (2015) memaparkan bahwa responden terpapar asap rokok lingkungan terbanyak berada pada rentang 16 - 25 tahun.82 Penelitian yang dilakukan oleh Luo (2011) menunjukkan bahwa paparan terbanyak dan terlama yaitu saat kecil yaitu lebih dari 10 tahun, dari rumah kurang dari 20 tahun, dan dari tempat kerja kurang dari 10 tahun.

Saat ini, selain paparan asap rokok lingkungan, Third Hand Smoke (THS) juga mulai diteliti untuk melihat apakah terdapat hubungan antara THS dengan kanker. THS merupakan residu asap pembakaran rokok yang menempel di setiap permukaan dan dapat bertahan lama yang dapat menimbulkan efek buruk bagi kesehatan. Setiap orang rentan terhadap paparan asap rokok lingkungan, sedangkan anak-anak, terutama balita, juga sangat rentan terhadap paparan THS. Balita lebih cenderung berguling-guling di karpet yang terkontaminasi atau menghirup partikel debu yang mengandung NNK. Selama masa pertumbuhan dan perkembangan ini, NNK dari THS memiliki efek yang signifikan pada perkembangan sistem organ termasuk jaringan payudara.

\section{Simpulan}

Penelitian ini, dapat disimpulkan bahwa sebanyak $90(84,1 \%)$ pasien terpapar asap rokok lingkungan, yaitu lima kali lipat lebih banyak dari yang tidak terpapar asap rokok lingkungan.

\section{Ucapan Terima Kasih}

Terima kasih penulis ucapkan kepada semua pihak yang telah membantu penyelesaian penelitian ini.

\section{Daftar Pustaka}

1. WHO (2014). Health Topic Cancer. World Health Organization.

https://www.who.int/topics/cancer/en/ - Diakses Desember 2019.

2. Russo I, Russo J. Pregnancy-induced changes in breast cancer risk. J Mammary Gland Biol Neoplasia. 2011. 16(3)221-3.

3. Globocan (2018). Estimated cancer incidence, mortality and prevalence worldwide in 2018. International Agency for Research on Cancer Internet. https://www.uicc.org/news/new-globalcancer-data-globocan-2018. Diakses Agustus 2019.

4. Globocan (2012). Estimated cancer incidence, mortality and prevalence worldwide in 2012. International Agency for Research on Cancer Internet. https://www.uicc.org/news/new-global- cancer-data-globocan-2012 - Diakses Agustus 2019.

5. IARC (2012). Breast Cancer Estimated Incidence, Mortality and Prevalence Worldwide in 2019. (hp://globocan.iarc.fr/Pages/fact_sheets_cancer. aspx - Diakses Desember 2019.

6. Pusdatin (2019). Bulan Peduli Kanker. Kementrian Kesehatan Republik Indonesia. https://pusdatin.kemkes.go.id/download.php?file=d ownload/pusdatin/infodatin/InfoDatin-Bulan-

Peduli-Kanker-Payudara-2016.pdf - Diakses Desember 2019.

7. Kemenkes (2019). Hari kanker sedunia 2019. http://www.depkes.go.id/article/view/1902010000 3/hari-kanker-sedunia-2019.html - Diakses Agustus 2019.

8. Kemenkes RI. Laporan hasil riset kesehatan dasar (Riskesdas) Indonesia tahun 2013. Jakarta: Badan Penelitian dan Pengembangan Kesehatan Kemenkes RI; 2013.

9. Sukmayenti, Sari, Nirmala. Analisis determinan kanker payudara pada wanita di RSUP Dr. M. Djamil Padang tahun 2018. Jurnal Kesehatan. Indonesia. 2019;1.

10. Kamińska M, Ciszewski T, Łopacka-Szatan K, Miotła P, Starosławska E. Breast cancer risk factors. Prz Menopauzalny. 2015;14(3):196-202.

11. Leader (2019). Health risks of secondhand smoke. https://www.verywellhealth.com/the-health-risksof-secondhand-smoke-915020. Diakses September 2019.

12. Betts KS. Secondhand suspicions: Breast cancer and passive smoking. Environ Health Perspect. 2007;115(3):136-43.

13. Tan YL, Ulysses Dorotheo. Tobacco Control Atlas ASEAN Region. 4th Ed. Southeast Asia Tobacco Control Alliance (SEATCA). Thailand; 2018.

14. Kemenkes RI. Laporan hasil riset kesehatan dasar (Riskesdas) Indonesia tahun 2018. Jakarta: Badan Penelitian dan Pengembangan Kesehatan Kemenkes RI; 2018.

15. Tobacco Control Support Centre-IAKMI. Bunga rampai fakta tembakau dan permasalahannya di Indonesia tahun 2014. Tobacco Control Support Centre-IAKMI. Kementrian Kesehatan. Jakarta; 2015.

16. WHO. Global Adult Tobacco Survey: Indonesia Report 2011. Jakarta; 2012.

17. WHO. (2019). Tubuh Tembakau. World Health Organization.

https://apps.who.int/iris/bitstream/handle/10665/ 324846/WHO-NMH-PND-19.1-ind.pdf?ua=1. Diakses April 2020.

18. Elizabeth T.H.. et al., Environmental Tobacco Smoke and Lung Cancer in Nonsmoking Women, JAMA. 1994;271(22):1752-5. 